\title{
Priming of Neutrophils and Differentiated PLB-985 Cells by Pathophysiological Concentrations of TNF- $\alpha$ Is Partially Oxygen Dependent
}

\author{
A. Paige Davis Volk Brieanna M. Barber Kelli L. Goss Jake G. Ruff \\ Christine K. Heise Jessica S. Hook Jessica G. Moreland \\ Division of Critical Care, Department of Pediatrics, Inflammation Program, University of lowa and Veterans Affairs \\ Medical Center, lowa City, lowa, USA
}

\section{Key Words}

Chemotaxis $\cdot$ Cytokines $\cdot$ Endotoxin $\cdot$ Oxidative burst $\cdot$

Sepsis $\cdot$ Reactive oxygen species $\cdot$ NADPH oxidase

\begin{abstract}
Activation of polymorphonuclear leukocytes (PMN) can be modulated to intermediate 'primed' states characterized by enhanced responsiveness to subsequent stimuli. We studied priming in response to TNF- $\alpha$ in human PMN and PLB-985 cells, a myeloid cell line differentiated to a neutrophilic phenotype (PLB-D). PMN generated reactive oxygen species (ROS) in response to TNF- $\alpha$ alone, and NADPH oxidase activity increased in response to stimulation with formylMet-Leu-Phe after priming. PLB-D cells also demonstrated priming of NADPH oxidase activity. Similar to priming by endotoxin, priming of the respiratory burst by TNF- $\alpha$ was predominantly oxygen dependent, with marked attenuation of ROS generation if primed anaerobically. Both PMN and PLB-D cells displayed significant increases in cell surface $\mathrm{CD} 11 \mathrm{~b}$ and gp91 ${ }^{\text {phox }}$ expression after TNF- $\alpha$ priming and PMN displayed activation of MAPK. In response to TNF- $\alpha$ priming, neither mobilization of intracellular proteins nor activation of MAPK pathways was NADPH oxidase dependent. Priming of PMN and PLB-D cells by low TNF- $\alpha$ concentrations enhanced chemotaxis. These data demonstrate that patho-
\end{abstract}

physiological concentrations of TNF- $\alpha$ elicit NADPH oxidasederived ROS and prime cells for enhanced surface protein expression, activation of $\mathrm{p} 38$ and ERK1/2 MAPK pathways, and increased chemotaxis. Furthermore, PLB-D cells undergo TNF- $\alpha$ priming and provide a genetically modifiable model to study priming mechanisms.

Copyright $\odot 2010$ S. Karger AG, Basel

\section{Introduction}

The incidence of sepsis continues to increase $[1,2]$ and, although it is clear that there are detrimental consequences of excessive polymorphonuclear leukocyte $(\mathrm{PMN})$ activation, the requirement for intact neutrophil function during bacterial sepsis has been demonstrated unequivocally. PMN priming induces enhanced readiness for rapid response to a subsequent stimulus and facilitates progression to full activation. A critical aspect of PMN priming as an intermediate level of activation is that primed PMN do not release proteolytic granular contents in response to the priming stimulus. Thus, priming plays a potentially protective role through the prevention of secondary damage to surrounding host cells. Primed PMN have been demonstrated in the circulation of patients during sepsis $[3,4]$ and other inflamma-

\section{KARGER}

Fax +41613061234

E-Mail karger@karger.ch

www.karger.com
(C) 2010 S. Karger AG, Basel

Accessible online at: www.karger.com/jin
Dr. Jessica G. Moreland

Division of Pediatric Critical Care, Department of Pediatrics

The University of Iowa

200 Hawkins Drive, Iowa City, IA 52242 (USA)

Tel. +1 319356 1615, Fax +1 3193568443 , E-Mail jessica-moreland@uiowa.edu 
tory disease processes [5], and have been extensively studied in vitro. Although the classical definition of priming suggests that there is not 'full activation' of the NADPH oxidase in response to a priming stimulus [6], we have recently demonstrated that the priming stimulus endotoxin elicits low-level reactive oxygen species (ROS) generation, in addition to priming PMN for an enhanced respiratory burst in response to subsequent stimuli [7].

A number of diverse agents have priming effects on $\mathrm{PMN}$, and both the underlying mechanisms of priming and the primed PMN phenotype are variable and dependent on the stimulus (reviewed by Condliffe et al. [8]). TNF- $\alpha$, an inflammatory cytokine released during sepsis, has been extensively studied as a priming agent for PMN functions. The clinical relevance for better understanding the phenomenon of priming by TNF- $\alpha$ is underscored by clear evidence that low levels of TNF- $\alpha$ are present in the circulation of patients with sepsis and, in some cases, increasing TNF- $\alpha$ levels inversely correlated with survival [9-11].

The phenotype of TNF- $\alpha$-primed cells includes an enhanced oxidative burst in response to future stimuli [12], increased surface levels of the $\beta_{2}$-integrins [13] and improved cell migration [14]. Review of this literature is complicated by the wide variation in TNF- $\alpha$ concentrations used to 'prime cells, ranging from 1 to $200 \mathrm{ng} / \mathrm{ml}$. However, the majority of studies employed at least $10 \mathrm{ng} /$ $\mathrm{ml}$ [15-17], a concentration that is significantly in excess of the range commonly seen in patient serum samples $(30-1,300 \mathrm{pg} / \mathrm{ml})$ [9-11]. Similarly, investigations of the mechanisms and signaling pathways responsible for these changes in PMN function used greater than physiologic concentrations, with the rare study employing a range of TNF- $\alpha$ concentrations that includes pathophysiologically relevant levels [18].

We recently reported our studies of endotoxin-mediated priming of human PMN and demonstrated that the development of the primed state requires both NADPH oxidasegenerated ROS and the anion transporter chloride channel-3 (CIC-3) [7]. The phagocyte NADPH oxidase is a multicomponent enzyme complex that produces substantial quantities of ROS necessary for optimal microbicidal activity against many pathogens. In addition, low levels of ROS are generated by PMN for signaling purposes and have been demonstrated to be involved in the regulation of integrin activation [19] and apoptosis [20]. Our recent investigation provides additional evidence that NADPH oxidasegenerated ROS signaling is required for PMN priming.

Further dissection of the mechanism of CIC-3 interaction with NADPH oxidase function in human PMN priming has been hampered by a lack of selective inhibitors for anion transporters and the inability to transfect human neutrophils. In the current study, we focused on priming by the cytokine TNF- $\alpha$ and studied both primary human PMN and the myeloid cell line PLB-985 differentiated to a neutrophilic phenotype. The goals of the current study included: (1) investigation of the primed PMN phenotype in response to TNF- $\alpha$ using a range of concentrations of this cytokine, consistent with levels detected in human serum during sepsis; (2) determination of the oxygen dependence of the TNF- $\alpha$ priming process; (3) characterization of priming in a genetically modifiable cell line for future use. Herein, we show that both PMN and PLB-D cells undergo priming by TNF- $\alpha$ for enhanced NADPH oxidase activity, increased cell surface receptor expression and improved chemotaxis. These events occur with priming concentrations of TNF- $\alpha$ as low as $1 \mathrm{pg} / \mathrm{ml}$. Alterations in directional motility as a result of TNF- $\alpha$ priming vary based on the concentration of the cytokine presented. Furthermore, TNF- $\alpha$-mediated priming of the respiratory burst is partially oxygen dependent in both cell types, as significantly reduced priming occurs under anaerobic conditions. The mechanism of NADPH oxidase involvement appears distinct from that seen in endotoxin priming, as upregulation of $\mathrm{CD} 1 \mathrm{lb}$ and activation of $\mathrm{p} 38 \mathrm{MAPK}$ occur in an NADPH oxidase-independent manner.

\section{Materials and Methods}

\section{Materials}

Hank's balanced salt solution (HBSS) was obtained from BioWhittaker (Walkersville, Md., USA). Fetal bovine serum (FBS) was obtained from HyClone (Logan, Utah, USA). RPMI 1640, Lglutamine, penicillin, streptomycin and HEPES were purchased from Cellgro (Manassas, Va., USA). Dimethyl formamide (DMF) and formyl-Met-Leu-Phe (fMLF) were purchased from Fisher Scientific (Pittsburgh, Pa., USA). Nutridoma was purchased from Roche (Madison, Wisc., USA). Murine anti-human CD11b was purchased from Pharmingen (San Diego, Calif., USA). Fluorescently conjugated secondary antibodies were from Jackson ImmunoResearch Laboratories (West Grove, Pa., USA). Mouse IgG was purchased from Sigma (St. Louis, Mo., USA). Antibody (clone 7D5) to the gp91 ${ }^{\text {phox }}$ component of the flavocytochrome $b_{558}$, the membrane-bound subunit of NADPH oxidase, was purchased from Medical and Biological Laboratories (Nagoya, Japan). Recombinant TNF- $\alpha$ was purchased from R\&D Systems (Minneapolis, Minn., USA). Paraformaldehyde was purchased from Electron Microscopy Sciences (Hatfield, Pa., USA). The fluorescein derivative formyl-Nle-Leu-Nle-Tyr-Lys (F-N) was purchased from Invitrogen (Carlsbad, Calif., USA). Additional reagents were all obtained from Sigma. 


\section{Human PMN Purification}

Human PMN were isolated according to standard techniques from heparin anti-coagulated venous blood from healthy, consenting adults in accordance with a protocol approved by the Institutional Review Board for Human Subjects at the University of Iowa. PMN were isolated using dextran sedimentation and Hypaque-Ficoll density-gradient separation, followed by hypotonic lysis of erythrocytes as previously described [21]. PMN purity using this method of isolation was greater than 95\%. PMN were maintained in HBSS without calcium and magnesium until used experimentally, always within 10 min of completion of the isolation process. Unless otherwise specified, $1 \%$ human serum albumin and $0.1 \%$ dextrose were added to commercial HBSS with calcium and magnesium as the working buffer solution for all assays of PMN function. In whole blood flow cytometry assays, heparinized whole blood was obtained and used within $10 \mathrm{~min}$ of phlebotomy.

\section{Cell Culture and Differentiation of PLB-985 Cells}

The human myeloid leukemia cell line PLB-985 (a generous gift from Dr. William M. Nauseef, Iowa City, Iowa, USA) was cultured in RPMI 1640 medium supplemented with L-glutamine, penicillin, streptomycin, HEPES and $10 \%$ heat-inactivated FBS, and cells were maintained at $37^{\circ} \mathrm{C}$ with $5 \% \mathrm{CO}_{2}$ and passaged twice weekly. Granulocytic differentiation of cells was accomplished according to previously published methods [22]. Briefly, the cell culture medium was replaced with RPMI 1640 medi-um supplemented with L-glutamine, penicillin, streptomycin, HEPES, 0.5\% heat-inactivated FBS, $0.5 \%$ DMF and $1 \%$ Nutridoma, and cells were maintained at $37^{\circ} \mathrm{C}$ with $5 \% \mathrm{CO}_{2}$. The differentiation medium was changed after 3 days in culture. Differentiated cells were used for experiments after 6 days in differentiation culture medium. In one series of experiments, a stable line of PLB-985 cells with targeted disruption of gp91 ${ }^{\text {phox }}$ (a gift from Mary Dinauer), X-CGD cells, were used to discern the role of the NADPH oxidase in $\mathrm{p} 38 \mathrm{MAPK}$ activation elicited by TNF- $\alpha$ priming.

\section{Priming of PMN or PLB-D Cells}

In priming studies, isolated PMN or PLB-D cells were incubated with TNF- $\alpha$ at a range of concentrations as described in individual results. Incubations occurred at $37^{\circ} \mathrm{C}$ for all priming studies for 10-60 min, as specified. In order to minimize the effects of the PMN isolation process on measured functional endpoints, cells were used within $10 \mathrm{~min}$ of completion of isolation. In some assays, these results were compared directly with studies of PMN in whole blood.

\section{Analysis of Oxygen Dependence of the Priming Process}

To assess the requirement for oxygen during the priming process, some priming studies were conducted in an anaerobic chamber (Bactron II; Sheldon Manufacturing, Cornelius, Oreg., USA). PMN or PLB-D cells were brought into the anaerobic chamber and primed with TNF- $\alpha$ under anaerobic conditions. Cells were then removed from the chamber, and immediately placed on ice and assayed for NADPH oxidase activity in response to FMLF, or studied by flow cytometry for mobilization of intracellular stores of proteins, as described below. Conditions in the anaerobic chamber were assessed by analysis of PMA-induced NADPH oxidase activity in the chamber as measured by the reduction of ferricytochrome $c$ (cyt $c$ ), see below. We have previously demonstrat- ed that PMN pretreatment with 30 min of anaerobic conditions does not alter PMN cell viability or levels of NADPH oxidase activity in response to serum opsonized zymosan (OpZ) and PMA [7].

\section{Measurement of NADPH Oxidase Activity}

Chemiluminescence

Lucigenin-enhanced chemiluminescence (LUC-CL) assays of NADPH oxidase activity were performed in a 96-well plate using the Fluostar Omega (BMG Technologies, Troy, Mich., USA). Two hundred microliter of a PMN suspension containing $2.5 \times 10^{6}$ $\mathrm{PMN} / \mathrm{ml}$ in HBSS with $1 \%$ HSA and $0.1 \%$ dextrose was added to each well with the final concentration of lucigenin $(100 \mu \mathrm{M})$. PLB cells were initially stimulated by addition of either OpZ (5 particles per cell) or PMA $10 \mathrm{ng} / \mathrm{ml}$ final concentration. For priming experiments, cells were stimulated by addition of TNF- $\alpha$ (100 pg/ $\mathrm{ml}$ to $100 \mathrm{ng} / \mathrm{ml}) \pm \mathrm{fMLF}$, as specified. Chemiluminescence was quantitated as relative light units using a kinetic assay with readings every minute for 30-90 $\mathrm{min}$.

\section{Reduction of cyt $c$}

Extracellular $\mathrm{O}_{2}{ }^{-}$generation was measured as the superoxide dismutase (SOD)-inhibitable reduction of cyt $c$ in a 96-well microplate using the Fluostar Omega. PMN suspensions were diluted and added to the microplate as described above. cyt $c$ (100 $\mu \mathrm{M})$ was added to the suspension just prior to loading in the microplate. In duplicate wells, SOD was added at a final concentration of $50 \mu \mathrm{g} / \mathrm{ml}$. The maximum rate $\left(\mathrm{V}_{\max }\right)$ of $\mathrm{O}_{2}{ }^{-}$generation and the total nanomoles $\mathrm{O}_{2}^{-} / \mathrm{min}$ was calculated as the SOD-inhibitable reduction of cyt $c$, with readings at absorbance $550 \mathrm{~nm}$ every $15 \mathrm{~s}$ for $30 \mathrm{~min}$ following injection of the stimulus, as specified. For assessment of oxygen tension in the anaerobic chamber, paired groups of triplicate wells loaded with PMN and cyt $c$ as described above were stimulated in the chamber with PMA (100 $\mathrm{ng} / \mathrm{ml}) \pm$ SOD. After $10 \mathrm{~min}$, one set with PMA alone and one set with PMA + SOD were treated with diphenyleneiodonium (DPI), an inhibitor of flavoproteins, to inhibit further NADPH oxidase activity. The microplate was removed from the anaerobic chamber and incubated for an additional $10 \mathrm{~min}$ before endpoint readings were measured. The percent inhibition of NADPH oxidase activity in the anaerobic chamber was quantitated by comparing the SOD-inhibitable reduction of cyt $c$ in the wells treated with DPI prior to removal from the chamber to those wells allowed to incubate an additional 10 min under normoxic conditions. By comparison to previous studies, we used $85 \%$ reduction of NADPH oxidase activity in response to PMA as the cutoff for adequacy of anaerobic chamber function, correlating to an oxygen level of $<0.1 \%[23]$.

Analysis of Cell Surface Protein Expression by Flow Cytometry PMN were analyzed using a FACScalibur flow cytometer (BD Biosciences, Franklin Lakes, N.J., USA). For assessment of surface expression of gp91 ${ }^{\text {phox }}$ and CD11b, PMN or PLB-985 cells were incubated in HBSS buffer \pm TNF- $\alpha$, as specified. Following incubation, cells were centrifuged and resuspended in blocking buffer containing PBS with $2 \%$ nonfat dry milk, and $4 \%$ normal goat serum for $20 \mathrm{~min}$ on ice. Primary antibodies, including murine $\mathrm{IgG}_{1}$ control, anti-CD11b or anti-gp91 ${ }^{\text {phox }}$, all at final concentrations of $8.3 \mu \mathrm{g} / \mathrm{ml}$, were added after blocking and incubated for $1 \mathrm{~h}$ on ice. Cells were centrifuged and resuspended in FITC-con- 
jugated goat anti-mouse antibody at a 1:1,000 dilution and incubated for $30 \mathrm{~min}$ on ice. Cells were resuspended in buffer containing $5 \mu \mathrm{g} / \mathrm{ml}$ propidium iodide prior to analysis. In some experiments, DPI $(50 \mu \mathrm{M})$ was used to inhibit the NADPH oxidase. This concentration of DPI was chosen after preliminary studies demonstrated $>99 \%$ inhibition of superoxide generation in response to PMA as measured by reduction of cyt $c$, whereas $10 \mu \mathrm{M}$ DPI inhibited approximately $95 \%$ of superoxide [7]. To analyze cell surface fMLF receptor expression, PMN or PLB-985 cells were incubated in buffer \pm TNF- $\alpha$, as specified. Following incubation, cells were fixed for $30 \mathrm{~min}$ on ice in $4 \%$ paraformaldehyde. Cells were centrifuged, washed with ice-cold buffer, and resuspended at $2 \times 10^{6} \mathrm{PMN} / \mathrm{ml}$. F-N (10 nM final) was added in the absence or presence of an excess amount of fMLF $(5 \mu \mathrm{M})$ and tumbled for $30 \mathrm{~min}$ at room temperature in the dark, as described [24, 25]. For select assays, PMN surface expression of CD11b was analyzed by FACS using freshly obtained whole blood incubated with or without TNF- $\alpha$ and treated for $1 \mathrm{~h}$ on ice with primary antibodies: $\mathrm{IgG}_{1}$ control or anti-CD11b $(6.25 \mu \mathrm{g} / \mathrm{ml})$. Following incubation, RBCs were lysed using FACS lysis buffer (BD Biosciences) and PMN were washed, resuspended and incubated with FITC-conjugated goat anti-mouse secondary antibodies at 1:1,000 dilution for $30 \mathrm{~min}$ on ice, prior to washing and FACS analysis.

\section{Analysis of PMN Chemotaxis by EZ-TAXIScan Assay}

EZ-TAXIScan ${ }^{\mathrm{TM}}$ assays (Effector Cell Institute, Tokyo, Japan) were performed at $37^{\circ} \mathrm{C}$ using the assembled chemotaxis apparatus perfused in EZT buffer, as described $[25,26]$. Briefly, PMN at $1 \times 10^{7} / \mathrm{ml}$ were kept in HBSS without calcium and magnesium until ready for use. Cells were then diluted to $1 \times 10^{6} / \mathrm{ml}$ in HBSS with calcium and magnesium and treated with buffer (control) or with TNF- $\alpha(10 \mathrm{ng} / \mathrm{ml})$ and incubated for $30 \mathrm{~min}$ at $37^{\circ} \mathrm{C}$. In each of 6 separate channels in the apparatus, a PMN suspension (approx. $5 \mu \mathrm{l}$ of $1 \times 10^{6} / \mathrm{ml}$ ) was injected with a $10-\mu l$ microsyringe and cells were aligned along the edge of the PMN chambers using the fluid flow technique [26]. Chemoattractants $(1 \mu \mathrm{l}$ of fMLF or activated complement component 5, C5a, at specified concentrations) were then injected into the stimulus chambers (opposite from the PMN loading chambers) to form chemotactic spatial gradients. Data were recorded channel by channel at 1-second time-lapse intervals between channels, as described $[25,26]$. Chemotaxis assays were filmed for $60 \mathrm{~min}$, with an image collection rate of 3 frames/min. Cells were manually tracked using Image J software and the percentage of motile cells from each experimental condition was calculated. Cells moving with an average instantaneous velocity (IV) less than $3 \mu \mathrm{m} / \mathrm{min}$ were considered nonmotile and were not included in the calculation of average chemotaxis parameters. Assessment of directionality, or chemotactic index (CI), was calculated as the ratio of net path length toward the chemoattractant to total path length of an individual cell. Chemotaxis parameters were computed using data obtained from individual cell tracks from at least 5 separate experiments, with at least 50 cells analyzed per condition.

\section{Analysis of MAPK Phosphorylation by Immunoblotting}

PMN $\left(2 \times 10^{7}\right)$ were treated with TNF- $\alpha$ for the specified time points. Some PMN were treated with DPI $(50 \mu \mathrm{M})$ to inhibit the NADPH oxidase prior to incubation with TNF- $\alpha$. Following incubation, cells were centrifuged and lysed in PMN lysis buffer (100 mM Tris, $150 \mathrm{~mm} \mathrm{NaCl,} 2 \mathrm{mM} \mathrm{MgCl}_{2}$, 1\% Triton, 1 mM PMSF,
2\% leupeptin/pepstatin A) for $45 \mathrm{~min}$ at $4{ }^{\circ} \mathrm{C}$ with tumbling. Lysates were centrifuged at $14,000 \mathrm{rpm}$ for $7 \mathrm{~min}$ and removed to fresh tubes. Samples were heated to $103^{\circ} \mathrm{C}$ for $3 \mathrm{~min}$ prior to analysis by SDS-PAGE.

\section{Protein Electrophoresis and Immunoblotting}

Samples were resolved in an $11 \%$ gel by SDS-PAGE and then transferred to nitrocellulose. Blots were probed for phosphospecific p38 MAPK, ERK1/2 and JNK using the following antibodies: phospho-p38 MAP kinase (Thr180/Tyr182) antibody at 1:1,000 dilution; phospho-p44/42 MAPK (Thr202/Tyr204) rabbit monoclonal antibody at 1:2,000 dilution; phospho-SAPK/JNK (Thr183/ Tyr185) rabbit monoclonal antibody at 1:1,000 dilution (Cell Signaling Technology, Danvers, Mass., USA). To quantify relative amounts between experiments, blots were stripped and reprobed with phosphorylation state-independent antibodies to p38, ERK1/2 and JNK using the following antibodies: p38 MAP kinase antibody; p44/42 MAP kinase (137F5) rabbit monoclonal antibody; SAPK/JNK (56G8) rabbit monoclonal antibody all at 1:1,000 dilution (Cell Signaling Technology). Immunoblots were processed using Alexa Fluor 680 goat anti-rabbit secondary antibody (Invitrogen) and detection was performed using the Odyssey Infrared Imaging System (LI-COR Biosciences, Lincoln, Nebr., USA).

\section{Analysis of MAPK Phosphorylation by Flow Cytometry}

PLB-D or differentiated X-CGD PLB cells were incubated with or without TNF- $\alpha$ for the specified time points at $37^{\circ} \mathrm{C}$, then placed immediately on ice. Cells were centrifuged and resuspended in $4 \%$ paraformaldehyde and fixed for $30 \mathrm{~min}$ on melting ice. Cells were spun and washed with ice-cold PBS and resuspended in ice-cold acetone to permeabilize for $5 \mathrm{~min}$ on ice. Following permeabilization, cells were washed twice and resuspended for blocking on ice for 20 min Primary antibodies were added on ice for $1 \mathrm{~h}$ (anti-phospho p38 1:100 or anti-total p38 1:25). Cells were washed and incubated with goat-anti rabbit FITC-conjugated secondary for $30 \mathrm{~min}$ on ice and washed and resuspended in ice-cold PBS for analysis.

\section{Statistical Analysis}

Results are expressed as means \pm standard error of the mean. Statistical comparisons were performed by Student's t test, MannWhitney or two-way ANOVA with the Bonferroni test to analyze data with unequal variance between groups as appropriate. The percentage of motile PMN in individual PMN populations was assessed using $\chi^{2}$ analysis. A probability of $\mathrm{p} \leq 0.05$ was considered significant. $\mathrm{N}$ represents the number of experiments.

\section{Results}

\section{Priming of the Respiratory Burst in Human PMN by}

TNF- $\alpha$

We initially focused on characterizing both the direct and priming responses of the NADPH oxidase after stimulation with pathophysiological concentrations of TNF$\alpha$ in freshly isolated human PMN. We selected fMLF as 


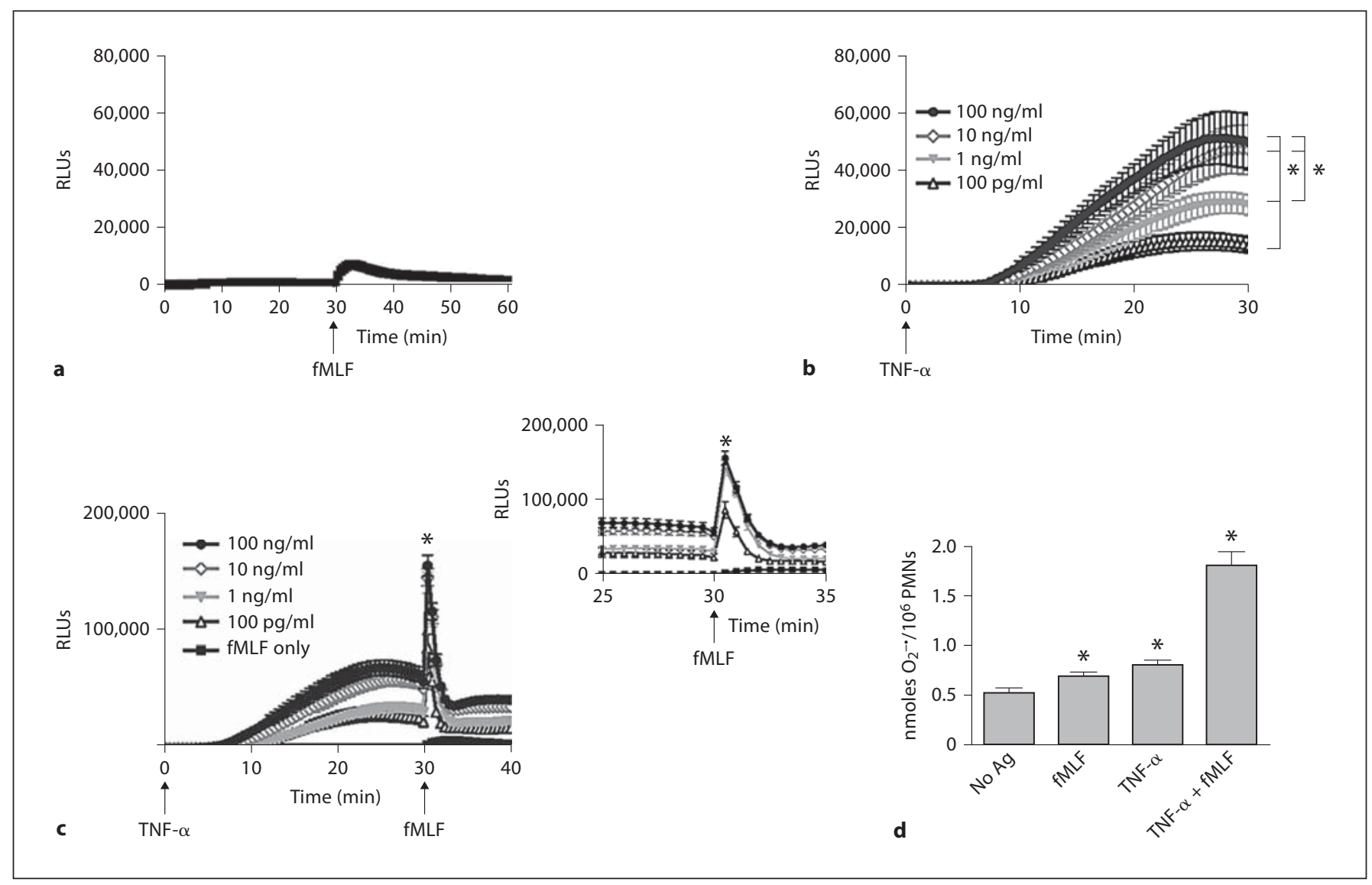

Fig. 1. NADPH oxidase activity in PMN in response to priming by TNF- $\alpha$. a Stimulation of untreated PMN with a weak agonist of NADPH oxidase activity, fMLF $(1 \mu \mathrm{M})$, elicited minimal NADPH oxidase activity as measured by LUC-CL. b NADPH oxidase activity was stimulated by TNF- $\alpha$ alone in a concentrationdependent manner with peak total ROS generation at approximately 25 min. ${ }^{*} \mathrm{p}<0.05$ for TNF- $\alpha(100 \mathrm{pg} / \mathrm{ml})$ versus 1,10 and $100 \mathrm{ng} / \mathrm{ml}$ and for TNF- $\alpha(1 \mathrm{ng} / \mathrm{ml})$ versus 10 and $100 \mathrm{ng} / \mathrm{ml}$. c PMN primed with TNF- $\alpha(1 \mathrm{ng} / \mathrm{ml})$ for $30 \mathrm{~min}$ prior to stimu- lation with fMLF $(1 \mu \mathrm{M})$ demonstrated a 44 -fold increase in ROS generation compared to PMN stimulated with $\mathrm{AMLF}$ alone. ${ }^{*} \mathrm{p}<0.05$. $\mathrm{N}=18-21$. d Measurement of extracellular superoxide generation by the SOD-inhibitable reduction of cyt $c$ demonstrated a minimal increase in extracellular ROS generation at $30 \mathrm{~min}$ in response to $\mathrm{fMLF}$ or TNF- $\alpha$ alone. However, PMN primed with TNF- $\alpha(1 \mathrm{ng} / \mathrm{ml})$ demonstrated a 3.4-fold increase in extracellular ROS generation following stimulation with fMLF (1 $\mu \mathrm{M})$ compared to untreated control cells at $30 \mathrm{~min},{ }^{*} \mathrm{p}<0.05 . \mathrm{N}=15$. the agonist for NADPH oxidase activity in the priming studies as it is well described to be a weak agonist of the respiratory burst in nonprimed cells, but elicits significantly enhanced ROS production after priming. As we have previously reported [7], stimulation of PMN with fMLF alone $(1 \mu \mathrm{M})$ elicited very low levels of total cellular NADPH oxidase activity as measured by LUC-CL (fig. 1a). We tested a broad range of TNF- $\alpha$ concentrations for priming ( $100 \mathrm{pg} / \mathrm{ml}$ to $100 \mathrm{ng} / \mathrm{ml})$, incubating cells with TNF- $\alpha$ for $30 \mathrm{~min}$. There was dose-dependent generation of ROS in response to TNF- $\alpha$ alone as measured by LUC-CL (fig. 1b). PMN primed for $30 \mathrm{~min}$ with all concentrations of TNF- $\alpha$ displayed marked enhancement in NADPH oxidase activity in response to subsequent stimulation with $\mathrm{fMLF}$ (fig. 1c). A 44-fold increase in peak ROS level after $\mathrm{fMLF}$ was seen in cells primed with the $1 \mathrm{ng} / \mathrm{ml}$ TNF- $\alpha$ concentration, compared to ROS generated in response to $\mathrm{fMLF}$ alone (fig. 1c, inset). To localize the ROS generated in response to the TNF- $\alpha$ priming stimulus, we used an additional assay of NADPH oxidase activity, the reduction of cyt $c$, which measures only extracellular generation of superoxide anion. The TNF- $\alpha$-primed burst in response to fMLF included significant extracellular generation of superoxide (3.4-fold 


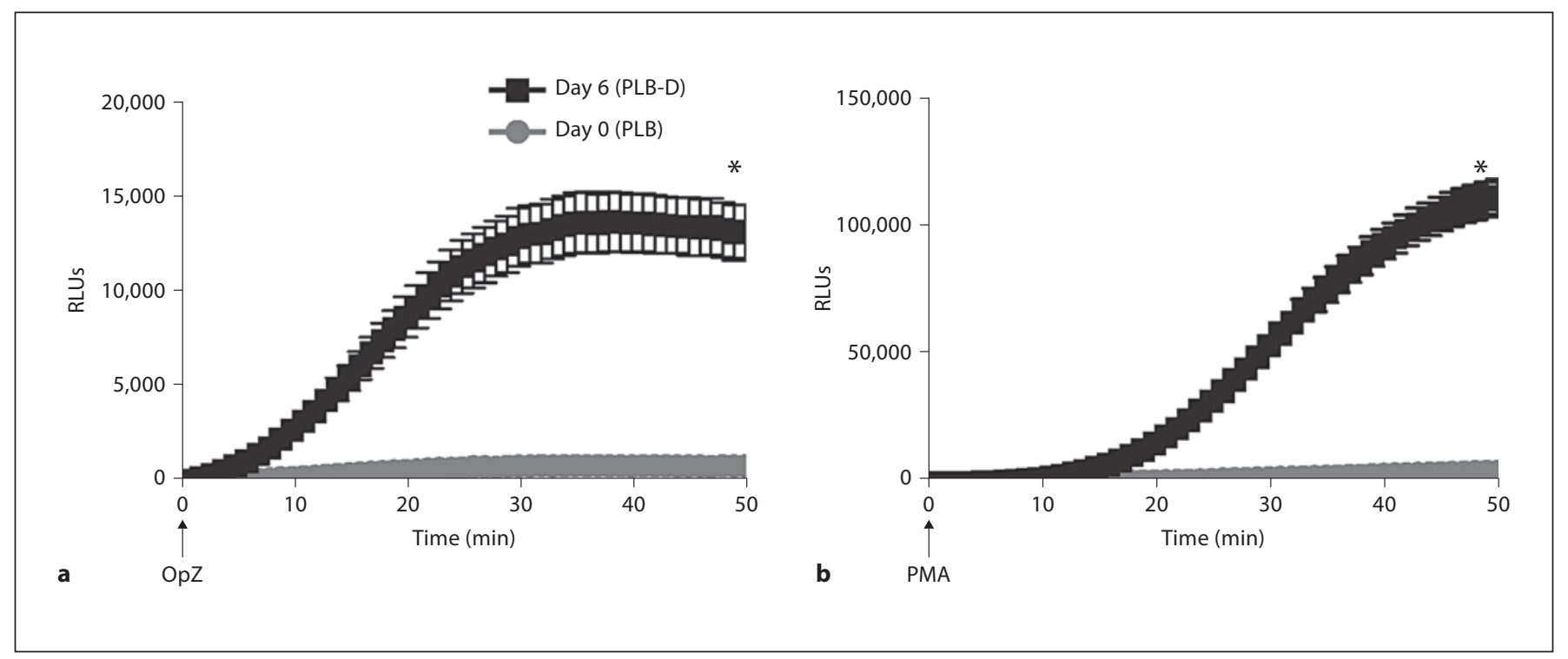

Fig. 2. NADPH oxidase activity in PLB-985 cells before and after differentiation. PLB-985 cells were kept undifferentiated in RPMI 1640 medium (day 0) or were differentiated for 6 days with RPMI 1640 with $0.5 \%$ FBS, 0.5\% DMF and 1\% Nutridoma (day 6). Using LUC-CL, PLB-D cells (day 6) demonstrated markedly enhanced NADPH oxidase activity in response to stimulation with the soluble agonist, PMA $(10 \mathrm{ng} / \mathrm{ml})(\mathbf{a})$, or in response to the particulate stimulus, OpZ, at a 5:1 particle:cell ratio as compared with undifferentiated PLB cells (day 0) (b). ${ }^{*} \mathrm{p}<0.05 . \mathrm{N}=15$.

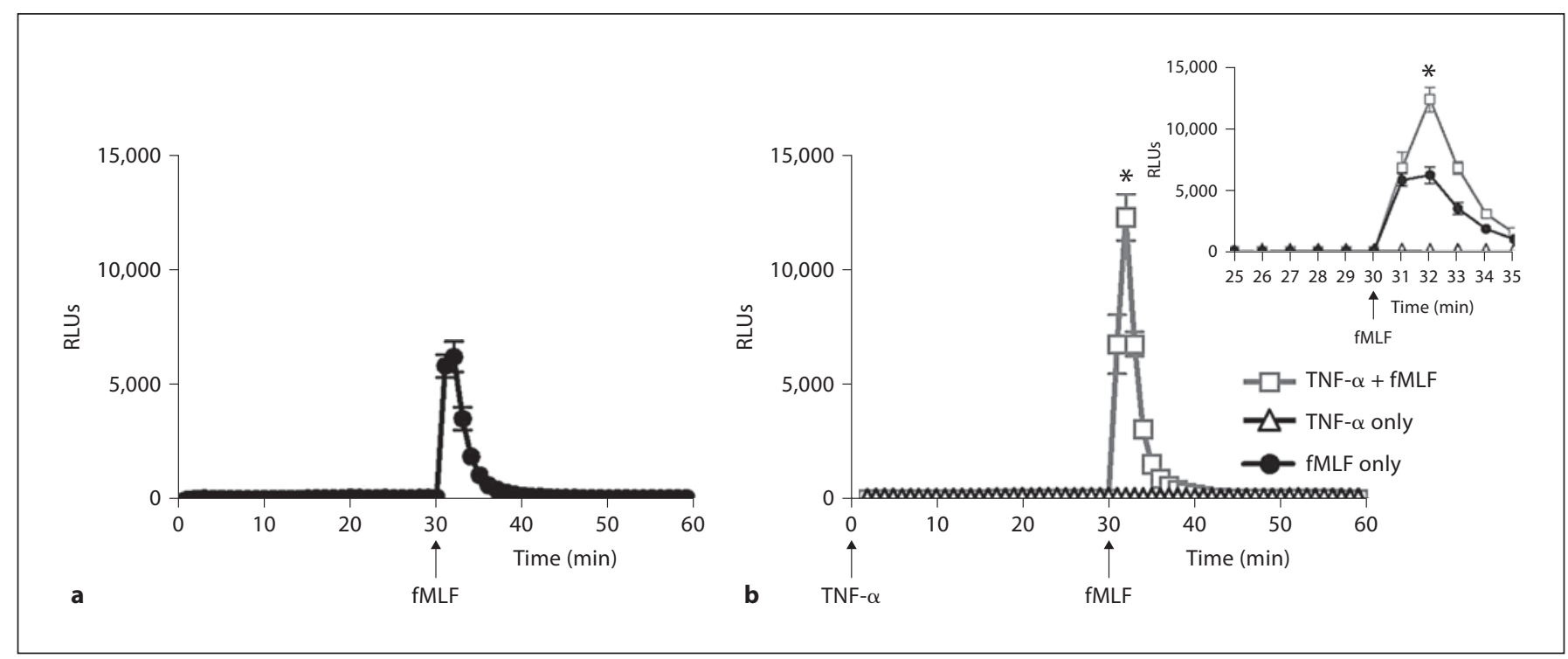

Fig. 3. NADPH oxidase activity in PLB-D cells in response to fMLF after priming by TNF- $\alpha$. a PLB-D cells demonstrated ROS generation in response to fMLF (100 nM) as measured by LUC-CL. b PLB-D cells primed by $30 \mathrm{~min}$ incubation with TNF- $\alpha(1 \mathrm{ng} / \mathrm{ml})$ demonstrated significant enhancement of the fMLF-stimulated respiratory burst. There were no detectable ROS generated in response to TNF- $\alpha$ alone. ${ }^{*} \mathrm{p}<0.05$ as compared to TNF- $\alpha$ only or fMLF. $\mathrm{N}=18$. 
increase in $\mathrm{O}_{2}{ }^{-}$in PMN stimulated with TNF- $\alpha$ and fMLF vs. unstimulated PMN at 30 min; fig. 1d). Lowlevel, but detectable, superoxide measured under unstimulated conditions represented NADPH oxidase activity occurring over time in our buffer conditions. Importantly, in contrast to the concentration-dependent total ROS stimulated by TNF- $\alpha$ alone as measured by LUC-CL (fig. 1b), the minimal increase in extracellular superoxide generation noted by reduction of cyt $c$ in response to TNF- $\alpha$ alone, as compared to fMLF or unstimulated PMN, does not account for the total ROS generated in response to TNF- $\alpha$. These data suggest that the ROS generated in response to the priming stimulus, TNF- $\alpha$, was predominantly intracellular.

Induction of NADPH Oxidase Activity in Response to Differentiation of PLB-985 Cells

We next sought to investigate priming by TNF- $\alpha$ in a genetically modifiable cell line. We selected the myeloid cell line PLB-985, as there was previous evidence of these cells' capacity to undergo priming by granulocyte macrophage colony-stimulating factor (GM-CSF). We used the differentiation protocol for PLB-985 cells described by Pedruzzi et al. [22] that demonstrates a greater percentage of cells differentiated into mature neutrophilic cells compared to previously reported methods. Using this protocol, we initially characterized the PLB cell cultures by microscopy according to the phenotypic characteristics initially described for these cells [27]. Following 6 days of differentiation, cells were $84 \pm 1.7 \%$ differentiated, with $15.5 \pm 1.7 \%$ in the undifferentiated category, 200 cells per experiment, $\mathrm{N}=12$. Consistent with previous reports [22], these differentiated PLB-D cells (day 6) displayed significant levels of NADPH oxidase activity as measured by LUC-CL, in response to both a particulate stimulus, OpZ (fig. 2a), and to the soluble agonist, PMA (fig. 2b). NADPH oxidase activity was not seen in the PLB-985 cells prior to the differentiation process (day 0). These data suggested that this differentiation approach was feasible for our studies of TNF- $\alpha$ priming.

Priming of NADPH Oxidase Activity in PLB-D Cells

We further investigated NADPH oxidase activity in response to the priming agent TNF- $\alpha$ and in response to fMLF after TNF- $\alpha$-mediated priming in PLB-D cells. As described above, fMLF was chosen as the postpriming stimulus because it is a weak agonist of the respiratory burst in resting PMN. However, the results of these studies in PLB-D cells were complicated because fMLF stimulated a much greater NADPH oxidase response in naïve (unprimed) PLB-D cells compared to unprimed PMN. A lower concentration of fMLF was studied to determine whether the direct NADPH oxidase response to fMLF might be reduced and priming effects more readily identified. Using $100 \mathrm{nM}$ fMLF as the agonist, there was still significant generation of ROS in PLB-D cells (fig. 3a), but there was also evidence of priming of the respiratory burst in PLB-D cells primed by TNF- $\alpha$ (fig. 3b, inset). There was no increase in the primed burst using higher concentrations of TNF- $\alpha$ for priming. Interestingly, in contrast to the studies in PMN, only minimal levels of ROS were detected in response to the priming agent TNF- $\alpha$ alone (fig. $3 b$ ).

\section{Cell Surface Expression of the fMLF Receptor in PMN} and PLB-D Cells

We reasoned that the enhanced NADPH oxidase activity seen in naive PLB-D cells in response to fMLF might be secondary to greater fMLF receptor density on the surface of unstimulated PLB-D cells as compared with unstimulated PMN. To test this we used flow cytometry to measure binding of F-N, a fluorescent ligand which binds to formyl-peptide receptor 1 [24]. We have previously confirmed that this ligand binds the fMLF receptor by competition studies with unlabelled fMLF [25]. Both PMN and PLB-D cells had easily detectable surface levels of fMLF receptor using this method, however, PMN had greater cell surface expression of the receptor than did PLB-D cells at rest (fig. 4). In response to stimulation with TNF- $\alpha, P M N$ displayed slightly enhanced levels of fMLF receptor expression that were independent of the TNF- $\alpha$ concentration but not significantly increased over unstimulated PMN. There was no increase in F-N binding following TNF- $\alpha$ stimulation of PLB-D cells. Considered in combination with the significant direct NADPH oxidase response to fMLF alone, it appeared that alternate endpoints to assess the primed phenotype in PLB-D cells would be necessary as cellular responses to fMLF stimulation may not be equivalent in PMN and PLB-D cells.

\section{Enhanced Cell Surface Protein Expression after}

TNF- $\alpha$ Priming in PMN and PLB-D Cells

Mechanisms underlying the generation of the primed phenotype have been described to include cell surface mobilization of intracellular stores of certain proteins, including adhesion molecules and subunits of the NADPH oxidase, such that primed cells display enhanced readiness to respond to subsequent stimuli. In view of our previous data demonstrating enhanced PMN surface ex- 


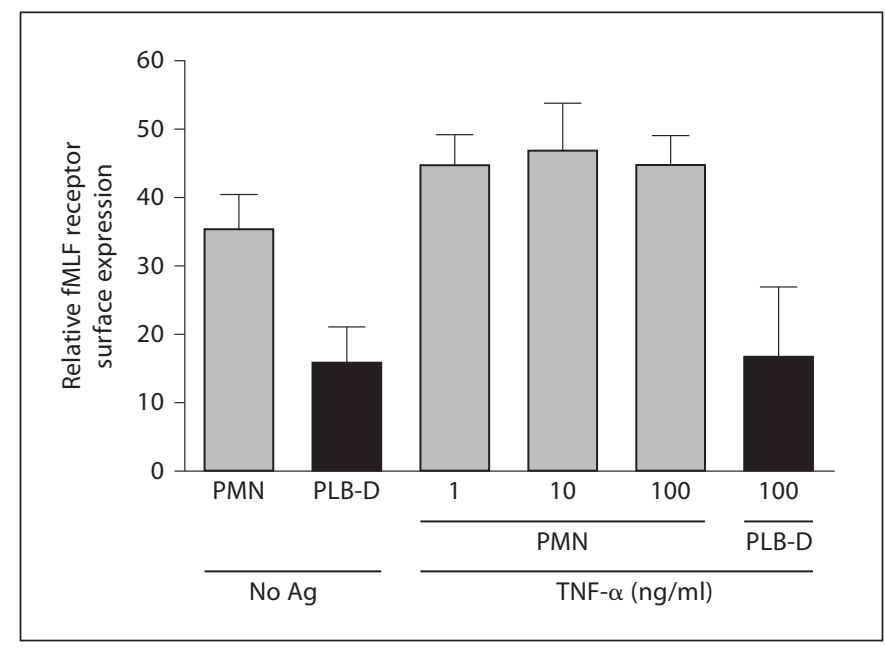

Fig. 4. Surface expression of fMLF receptor in PMN and PLB-D cells measured by flow cytometry. Cell surface levels of the fMLF receptor, as measured by binding of the fluorescent ligand, F-N, were higher in resting PMN than in unstimulated PLB-D cells. Incubation of PMN with TNF- $\alpha(1-100 \mathrm{ng} / \mathrm{ml})$ for $30 \mathrm{~min}$ elicited a trend towards increased receptor density that was not significant, however, PLB-D cells displayed no increase in F-N binding following treatment with the highest concentration of TNF$\alpha . \mathrm{N}=4-9$.

pression of gp91 ${ }^{\text {phox }}$ and the $\beta_{2}$-integrin CD11b following endotoxin priming [7], we elected to study these additional endpoints of priming for comparison between PMN and PLB-D cells treated with TNF- $\alpha$. It has been demonstrated previously that TNF- $\alpha$ priming elicits increased surface protein expression, although these studies employed significantly higher concentrations of TNF$\alpha$ than are found in vivo [13]. Using flow cytometry to measure cell surface molecule expression, we found that TNF- $\alpha(100 \mathrm{pg} / \mathrm{ml}$ to $100 \mathrm{ng} / \mathrm{ml})$ elicited significantly increased cell surface expression of both CD11b and gp91 ${ }^{\text {phox }}$. Priming PMN with $100 \mathrm{pg} / \mathrm{ml}$ TNF- $\alpha$, a concentration routinely found in the plasma of septic patients [9-11], increased cell surface levels of CD11b and gp91 ${ }^{\text {phox }}$ by 1.8 - and 1.4-fold, respectively, as compared to unstimulated PMN (fig. 5a-c). Similarly, although the magnitude of change was not as great as that seen in PMN, TNF- $\alpha(10 \mathrm{ng} / \mathrm{ml})$ elicited significant enhancement of these proteins on the PLB-D cell surface (fig. $5 \mathrm{~d}-$ e). These data provided further evidence that PLB-D cells are a genetically modifiable cell line suitable to study priming in combination with studies on primarily isolated human PMN, and that physiologically relevant concentrations of TNF- $\alpha$ elicit changes in cell surface protein expression in PMN.

Priming of PMN and PLB-985 Cells by TNF- $\alpha$
PMN and PLB-D Cell Chemotaxis Altered by TNF- $\alpha$

Priming in a Concentration-Dependent Manner

In view of the altered integrin levels observed in response to TNF- $\alpha$-mediated priming in both PMN and PLB-D cells, we evaluated an additional endpoint of priming, PMN directional migration in response to chemoattractants. The literature on effects of priming on chemotaxis is not straightforward and has been hampered by analysis of TNF- $\alpha$ concentrations in excess of those typically seen during sepsis in vivo. Previous studies have shown that high concentrations of TNF- $\alpha$ inhibit PMN chemotaxis $[28,29]$. In studies using more physiologically relevant TNF- $\alpha$ concentrations, enhanced PMN migration was observed [30, 31].

We explored potential alterations in chemotaxis in PMN and PLB-D cells primed with a range of TNF- $\alpha$ concentrations using the EZ-TAXIScan assay, which permits direct visualization of chemotaxis with measurement of individual cell directionality and velocity $[25$, 26]. TNF- $\alpha$ has been shown to alter $\mathrm{MLF}$ receptor-binding affinity [29], therefore, we assessed PMN chemotaxis in response to the anaphylatoxin, $\mathrm{C} 5 \mathrm{a}$, as well as to the classical chemoattractant, $\mathrm{fMLF}$, used in our prior priming studies. We employed a range of chemoattractant concentrations to characterize PMN chemotaxis in response to increasing chemoattractant spatial gradients. PMN primed with a higher concentration of TNF- $\alpha$ (10 $\mathrm{ng} / \mathrm{ml}$ ) demonstrated impaired directional migration (or mean CI) to $\mathrm{C} 5 \mathrm{a}$, with significant impairment in response to the $0.01 \mu \mathrm{M}$ C5a gradient compared to control PMN (fig. 6a). In contrast, PMN primed with low-level TNF- $\alpha(1 \mathrm{pg} / \mathrm{ml})$ demonstrated significantly enhanced chemotaxis in all studied C5a gradients compared to control PMN. In addition, PMN average IV was significantly decreased following priming with $10 \mathrm{ng} / \mathrm{ml} \mathrm{TNF}-\alpha$, but significantly increased after treatment with $1 \mathrm{pg} / \mathrm{ml}$ TNF- $\alpha$ in response to all studied C5a gradients (fig. 6b). These data were confirmed in our population analysis, demonstrating significantly altered motility curves for TNF- $\alpha$ primed PMN compared to control PMN (fig. 6c). No difference in CI or IV was noted between control and TNF- $\alpha$ ( $1 \mathrm{pg} / \mathrm{ml}$ or $10 \mathrm{ng} / \mathrm{ml}$ )-primed PMNs moving in the absence of a C5a gradient (data not shown). Importantly, when we tested the effect of TNF- $\alpha$ priming on chemotaxis in the PLB-985 cell line, PLB-D cells primed with $1 \mathrm{pg} / \mathrm{ml}$ TNF- $\alpha$ also demonstrated significantly enhanced chemotaxis compared to control cells in response to $1 \mu \mathrm{M}$ C5a (control CI $0.45 \pm 0.02$ vs. TNF- $\alpha$-primed CI $0.54 \pm 0.02, \mathrm{p}<0.05)$ and $0.01 \mu \mathrm{M}$ C5a (control CI $0.52 \pm 0.02$ vs. TNF- $\alpha$-primed CI $0.69 \pm 0.03$, p < 0.05).

J Innate Immun 2011;3:298-314 

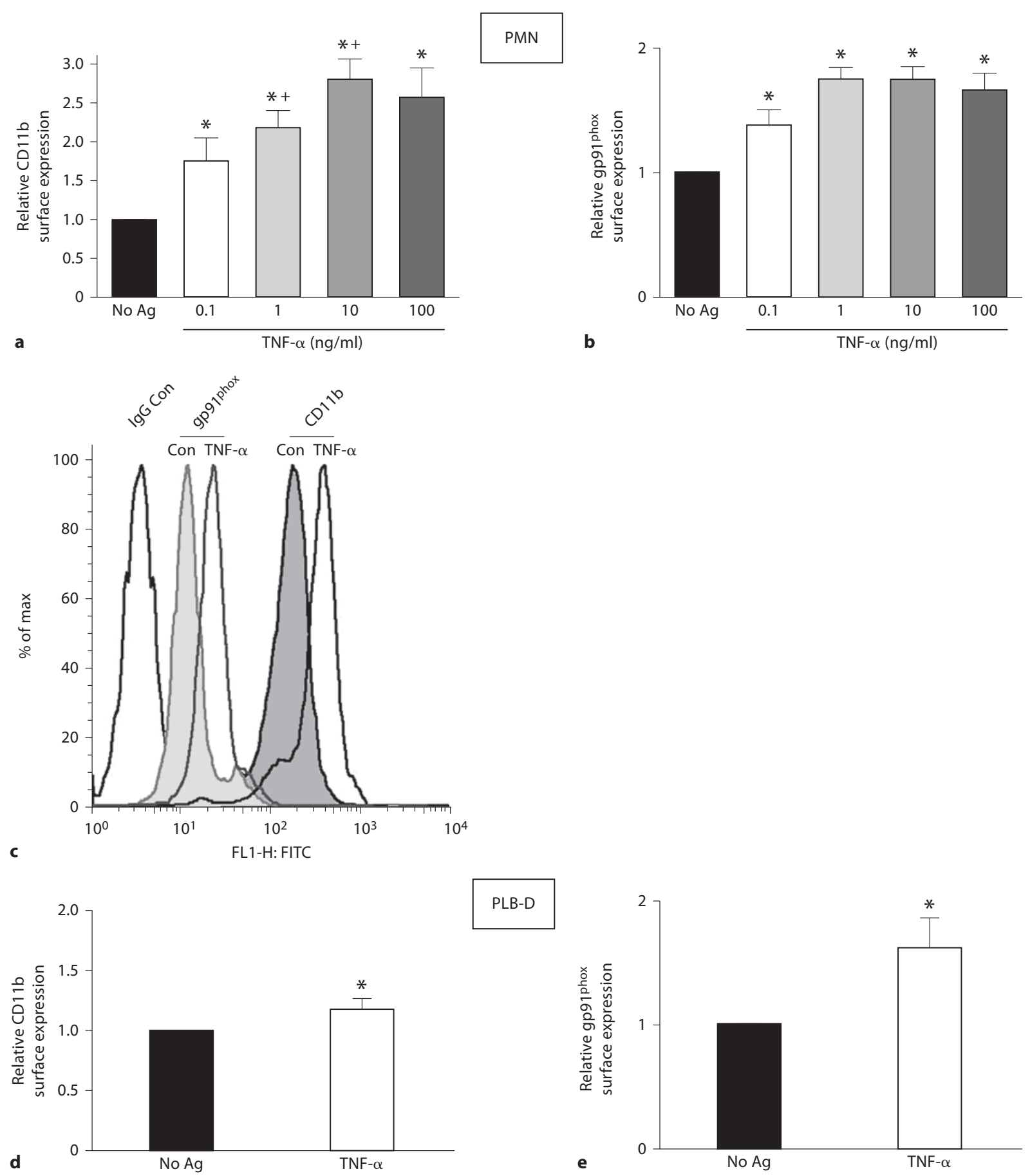

Fig. 5. Surface expression of CD11b and gp91 phox in PMN and PLB-D cells after priming by TNF- $\alpha$. As measured by flow cytometry, PMN treated with $0.1-100 \mathrm{ng} / \mathrm{ml} \mathrm{TNF}-\alpha$ for $30 \mathrm{~min}$ demonstrated a concentration-dependent enhancement in cell surface expression of the $\beta_{2}$-integrin, CD11b (a) and gp91 ${ }^{\text {phox }}$ levels (b). $\mathrm{N}=5(0.1 \mathrm{ng} / \mathrm{ml}), \mathrm{N}=8-12(1-100 \mathrm{ng} / \mathrm{ml}) .{ }^{*} \mathrm{p}<0.05$ as compared to No Ag control value; ${ }^{+} \mathrm{p}<0.05$ as compared with TNF- $\alpha(0.1$ $\mathrm{ng} / \mathrm{ml})$. c Representative histogram showing increase in CD11b and gp91 ${ }^{\text {phox }}$ surface expression after TNF- $\alpha(1 \mathrm{ng} / \mathrm{ml})$ in PMN. PLB-D cells treated with TNF- $\alpha(10 \mathrm{ng} / \mathrm{ml})$ also demonstrated significantly increased CD11b (d) and gp91 $1^{\text {phox }}$ (e) surface levels. ${ }^{*} \mathrm{p}<0.05$ as compared to No Ag control values. $\mathrm{N}=6-8$. 


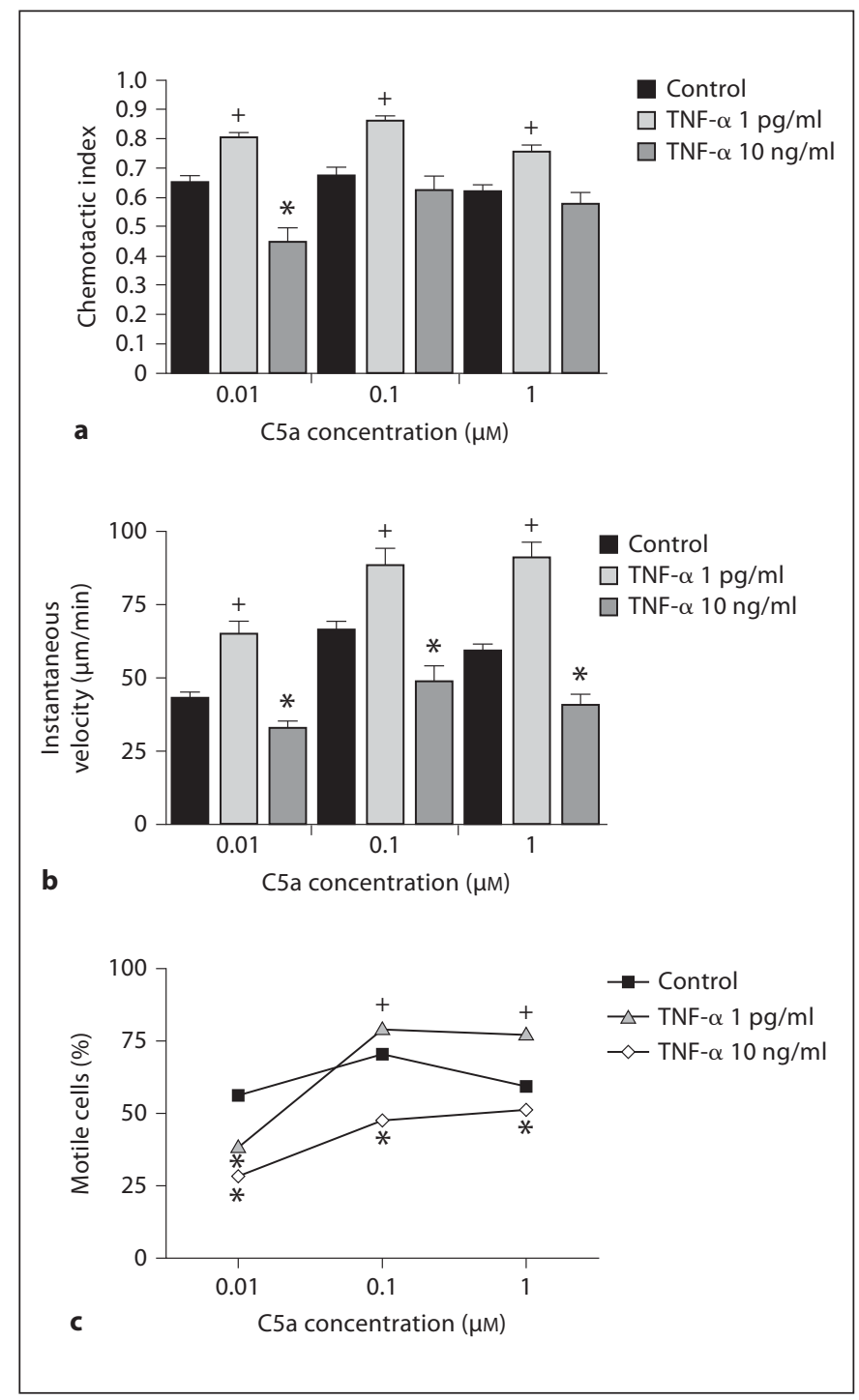

Fig. 6. PMN chemotaxis parameters in response to C5a spatial gradients after priming with TNF- $\alpha$. a PMN primed with TNF- $\alpha$ $(1 \mathrm{pg} / \mathrm{ml})$ had significantly increased average CI in response to $0.01,0.1$ and $1 \mu \mathrm{M}$ C5a spatial gradients compared to control PMN. PMN primed with a higher TNF- $\alpha$ concentration (10 ng/ $\mathrm{ml}$ ) had impaired average CI compared to control PMN, with significantly lower CI in response to $0.01 \mu \mathrm{M}$ C5a. b PMN primed with TNF- $\alpha(1 \mathrm{pg} / \mathrm{ml})$ had significantly increased average IV and PMN primed with TNF- $\alpha(10 \mathrm{ng} / \mathrm{ml})$ had significantly decreased average IV compared to control PMN. $\mathrm{N}=5-16$. c By $\chi^{2}$ analysis, PMN primed with TNF- $\alpha(1 \mathrm{pg} / \mathrm{ml})$ for 30 min demonstrated a reduced number of motile cells during the response to $0.01 \mu \mathrm{M}$ $\mathrm{C} 5 \mathrm{a}$, but a significantly higher percentage of motile cells during the response to 0.1 and $1 \mu \mathrm{M}$ C5a spatial gradients. PMN treated with TNF- $\alpha(10 \mathrm{ng} / \mathrm{ml})$ demonstrated a significantly reduced number of motile cells during the response to C5a at all tested spatial gradient concentrations. Values are the percentage of motile cells in each treatment population with $>150$ total cells/population. ${ }^{*}$ Denotes values significantly below control. ${ }^{+}$Denotes values significantly greater than control. $\mathrm{p}<0.05 . \mathrm{N}=5-16$.
Similar findings were seen in PMN responding to fMLF spatial gradients. PMN primed with $1 \mathrm{pg} / \mathrm{ml}$ TNF- $\alpha$ had increased average directional migration (control CI 0.74 \pm 0.02 vs. TNF- $\alpha$-primed CI $0.83 \pm 0.01, \mathrm{p}<0.05)$ and velocity (control IV $60.4 \pm 2.6 \mu \mathrm{m} / \mathrm{min}$ vs. TNF- $\alpha$ primed IV $71.9 \pm 3.5 \mu \mathrm{m} / \mathrm{min}, \mathrm{p}<0.05)$ compared to control PMN in response to $1 \mu \mathrm{M}$ fMLF. In contrast, PMN primed with $10 \mathrm{ng} / \mathrm{ml}$ TNF- $\alpha$ had decreased average CI compared to controls in response to fMLF gradients $(0.1 \mu \mathrm{M}$ fMLF: control CI $0.75 \pm 0.02$ vs. TNF- $\alpha$ primed CI $0.62 \pm 0.04, \mathrm{p}<0.05 ; 10 \mu \mathrm{M}$ fMLF: control CI $0.68 \pm 0.02$ vs. TNF- $\alpha$-primed $0.53 \pm 0.05, \mathrm{p}<0.05)$. These data suggest that TNF- $\alpha$ priming has concentration-dependent effects on PMN and PLB-D cell-directional motility and that PMN chemotaxis is enhanced by the pathophysiological TNF- $\alpha$ concentrations typically observed during sepsis in vivo.

\section{NADPH Oxidase Activity Not Required for TNF- $\alpha$} Activation of $p 38$ and ERK1/2 MAPKs

Intracellular signaling proteins involved in the prioritization of chemotactic responses, including the MAP kinases, are under investigation by multiple laboratories. We have previously demonstrated that priming of PMN by endotoxin elicits rapid phosphorylation of p38 MAPK that occurs in an NADPH oxidase-dependent manner [7]. Based on these data and the evidence that TNF- $\alpha$ generates a p38 MAPK-dependent stop signal involved in cell migration [31], we studied phosphorylation of the MAPK proteins in response to TNF- $\alpha$ under control conditions and in the setting of NADPH oxidase inhibition. Confirming the findings of others [18], with extended kinetic analysis, we demonstrated a time-dependent activation of p38 MAPK (fig. 7a) and ERK1/2 (fig. 7b) during incubation with TNF- $\alpha$, but no alteration in phosphorylation of JNK (fig. 7c). In contrast to our findings with endotoxin priming [7], this enhanced MAPK phosphorylation was not inhibited by pretreatment of PMN with DPI, an inhibitor of flavoproteins that impairs NADPH oxidase function. In view of these data, we also performed analysis of $\mathrm{p} 38$ MAPK activation in differentiated PLB cells, as well as X-CGD PLB cells (lacking gp91 ${ }^{\text {phox }}$ ). PLB-D cells demonstrated enhanced phosphorylation of p38 MAPK in response to TNF- $\alpha$ priming, although the magnitude of enhancement of activation was less than that seen in human PMN. Moreover, similar to our findings in DPItreated human PMN, X-CGD PLB cells also displayed increased levels of phosphorylated p38 MAPK during TNF$\alpha$ priming, with peak activation at 5 min after TNF- $\alpha$. (fig. 7d, e). 


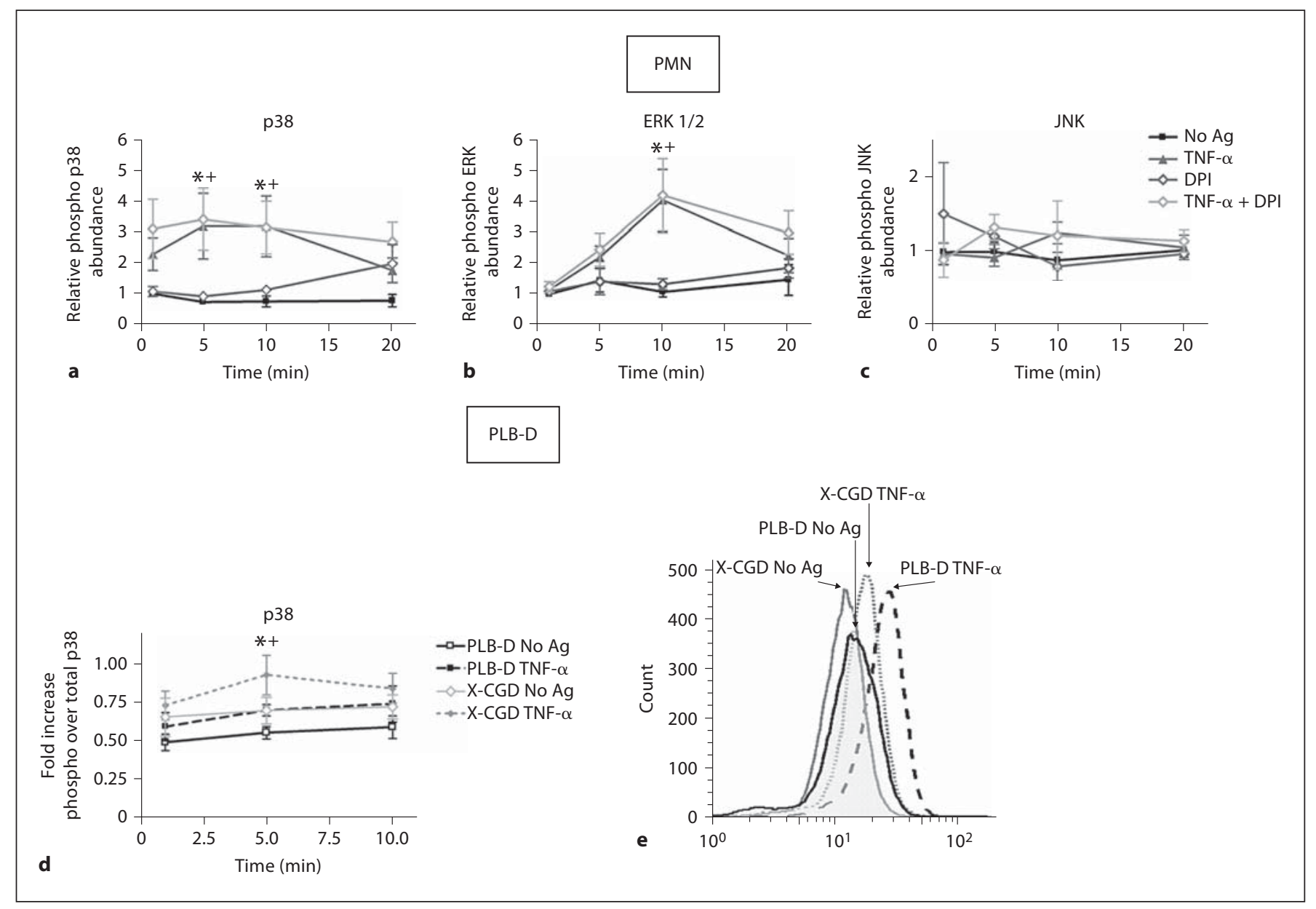

Fig. 7. NADPH oxidase activity not required for TNF- $\alpha$ activation of p38 and ERK 1/2 MAPKs. a-c In PMN, phosphorylation of p38, ERK1/2 and JNK was measured by protein isolation and immunoblotting following PMN stimulation with TNF- $\alpha(1 \mathrm{ng} / \mathrm{ml})$ in the presence or absence of DPI $(50 \mu \mathrm{M})$. a TNF- $\alpha$ priming of PMN elicited significantly higher amounts of phospho p38 than unstimulated (No Ag) control PMN at 5 and $10 \mathrm{~min} .{ }^{*} \mathrm{p} \leq 0.05$. $\mathrm{N}=7$. PMN treated with DPI demonstrated a similar enhancement in phospho p38 levels following TNF- $\alpha$ priming compared to cells treated with DPI alone. ${ }^{+} \mathrm{p} \leq 0.05 . \mathrm{N}=7$. $\mathbf{b} \mathrm{PMN}$ primed with TNF- $\alpha$ demonstrated a significant increase in phospho ERK1/2 compared to unstimulated (No Ag) control at the $10 \mathrm{~min}$ time point. ${ }^{*} \mathrm{p} \leq 0.05, \mathrm{~N}=7$. A significant increase in phospho

\section{Priming of PMN and PLB-D Cells by TNF- $\alpha$ Is}

\section{Oxygen Dependent}

This contrast in the NADPH oxidase dependence of p38 MAPK activation in response to TNF- $\alpha$ versus endotoxin priming suggested that TNF- $\alpha$ priming might not be oxygen dependent. Moreover, the absence of any direct ROS generation in response to the priming stimulus, TNF- $\alpha$, in PLB-D cells was notable in view of our previ-
ERK1/2 levels was also seen in primed PMN treated with DPI compared to PMN treated with DPI alone, ${ }^{+} \mathrm{p} \leq 0.05 . \mathrm{N}=7$. c TNF- $\alpha$ elicited no increase in relative abundance of phospho JNK and DPI treatment had no effect on phospho JNK levels. N = 4. d, e In PLB-D cells, phosphorylation of p38 MAPK was assessed by flow cytometry (relative to total p38 MAPK levels) following stimulation with TNF- $\alpha(1 \mathrm{ng} / \mathrm{ml})$. Both PLB-D cells and X-CGDPLB cells (lacking gp91 ${ }^{\text {phox }}$ ) demonstrated a significant increase in phospho p38 at the 5-min time point of priming with TNF- $\alpha$ as compared to unstimulated (No Ag) control cells. ${ }^{*}+\mathrm{p}<0.05$. $\mathrm{N}=$ 7. e Representative histogram demonstrating the $5 \mathrm{~min}$ time point in PLB-D and X-CGD cells \pm TNF- $\alpha$.

ous data suggesting that endotoxin priming is both oxygen and NADPH oxidase dependent [7]. We reasoned that the mechanisms underlying the primed phenotype might be different in response to TNF- $\alpha$, therefore, we investigated TNF- $\alpha$-mediated priming under anaerobic conditions. Following priming in the anaerobic chamber, cells were removed to room air for stimulation with fMLF and measurement of NADPH oxidase activity by LUC- 


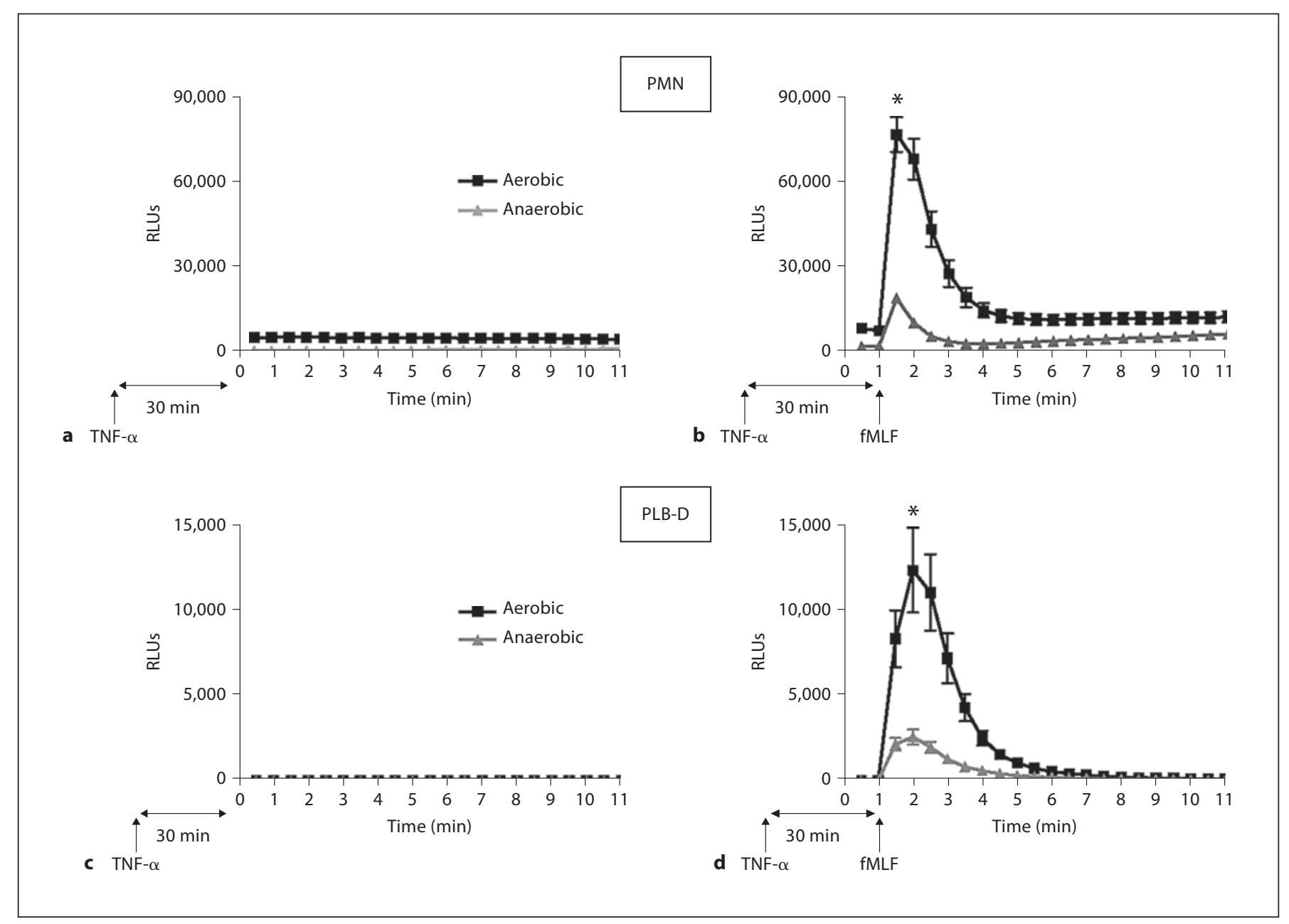

Fig. 8. Priming of PMN and PLB-D cells by TNF- $\alpha$ under anaerobic conditions. a TNF- $\alpha(1 \mathrm{ng} / \mathrm{ml})$ alone induced minimal NADPH oxidase activity under either aerobic or anaerobic conditions. b PMN primed with TNF- $\alpha$ ( $1 \mathrm{ng} / \mathrm{ml})$ under anaerobic conditions and then brought to room air had significantly decreased NADPH oxidase activity in response to fMLF as compared to PMN primed under normoxic (aerobic) conditions, as measured

CL. This permitted direct comparison between cells primed under aerobic (room air) versus anaerobic, but otherwise identical, conditions. When primed under anaerobic conditions, PMN demonstrated a dramatic reduction in the primed respiratory burst (fig. 8a, b). PMN primed with TNF- $\alpha(1 \mathrm{ng} / \mathrm{ml})$ for $30 \mathrm{~min}$ under anaerobic conditions had an $85.0 \%$ reduction in peak NADPH oxidase activity in response to fMLF, as compared with cells primed under aerobic conditions. For PLB-D cells, the primed burst was $79.0 \%$ reduced under anaerobic conditions (fig. 8c, d). This decrease in NADPH oxidase activity did not represent loss of cell viability based on by LUC-CL. ${ }^{*} \mathrm{p}<0.05 . \mathrm{N}=8 . \mathrm{c} \mathrm{TNF}-\alpha(1 \mathrm{ng} / \mathrm{ml})$ alone induced minimal NADPH oxidase activity in PLB-D cells under aerobic or anaerobic conditions. $\mathbf{d}$ PLB-D cells primed with TNF- $\alpha$ (1 ng/ $\mathrm{ml}$ ) under anaerobic conditions and then brought to room air displayed a marked oxygen dependence for the primed respiratory burst in cells following 30 min TNF- $\alpha$ priming. ${ }^{*} \mathrm{p}<0.05$. $\mathrm{N}=16$.

prior controls demonstrating normal PMA- and OpZ-induced ROS generation after 30 min under anaerobic conditions [7]. Despite the generation of negligible levels of ROS in response to the priming stimulus alone in PLB-D cells, the inhibition of priming under anaerobic conditions was strikingly similar to the phenotype seen in PMN. Importantly, some degree of priming occurred even under anaerobic conditions in both PMN and PLBD cells, suggesting both an oxygen-dependent and oxygen-independent pathway for PMN priming of the respiratory burst by TNF- $\alpha$. 


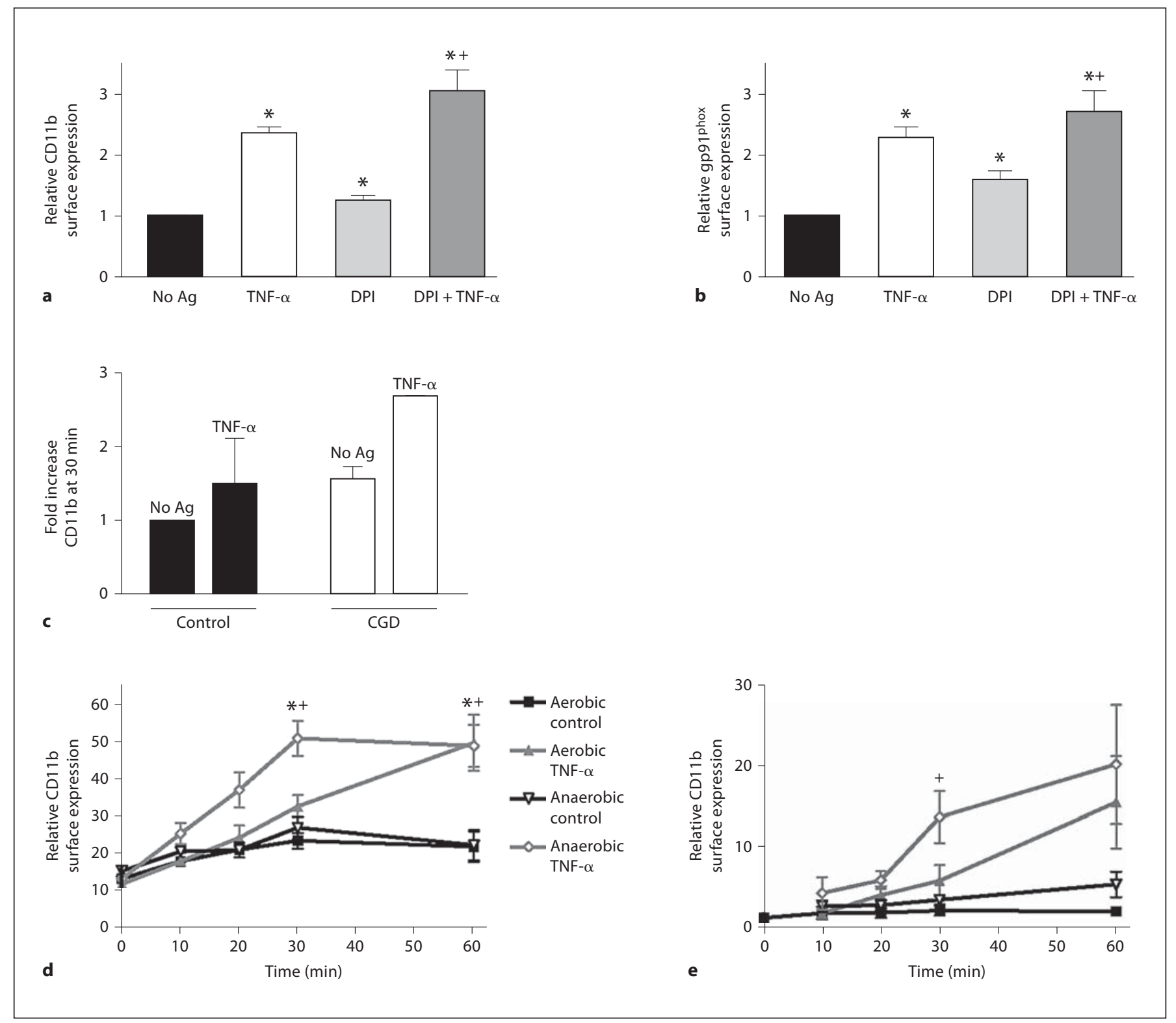

Fig. 9. PMN cell surface protein mobilization in response to TNF$\alpha$ is not NADPH oxidase dependent. As measured by flow cytometry, PMN pretreated with the flavoprotein inhibitor DPI $(50 \mu \mathrm{M})$ demonstrated no inhibition of CD11b (a) or gp91 ${ }^{\text {phox }}(\mathbf{b})$ surface expression in response to priming with TNF- $\alpha(10 \mathrm{ng} / \mathrm{ml})$ for 30 min PMN treated with DPI alone displayed significant mobilization of both CD11b and gp91 ${ }^{\text {phox }}$ in the absence of any other stimulus. ${ }^{*} \mathrm{p}<0.05$ as compared to No Ag control value, ${ }^{+} \mathrm{p}<0.05$ as compared to DPI-treated cells in the absence of TNF- $\alpha . \mathrm{N}=5-6$. c Surface mobilization of CD11b was studied in PMN from two patients with chronic granulomatous disease. PMN lacking functional NADPH oxidase demonstrated increased CD11b surface expression compared to normal control PMN at rest (No Ag) or in response to TNF- $\alpha$ ( $1 \mathrm{ng} / \mathrm{ml}) . \mathrm{N}=2$. Kinetic analysis of PMN $\mathrm{CD} 11 \mathrm{~b}$ surface mobilization under standard isolation conditions (d) or in whole blood (e). d Control PMN isolated by standard techniques were primed aerobically or anaerobically with TNF- $\alpha$ ( $1 \mathrm{ng} / \mathrm{ml}$ ). PMN primed with TNF- $\alpha$ under anaerobic conditions had more rapid enhancement of surface CD11b levels than cells primed aerobically, with nearly identical levels of surface protein mobilization by 60 min. ${ }^{*} \mathrm{p}<0.05$ as compared to aerobic control; ${ }^{+} \mathrm{p}<0.05$ as compared to anaerobic control. $\mathrm{N}=5-9$. e PMN in whole blood stimulated with TNF- $\alpha(1 \mathrm{ng} / \mathrm{ml})$ under aerobic and anaerobic conditions demonstrated TNF- $\alpha$-elicited changes in CD11b surface levels similar to the changes seen in PMN isolated by standard techniques. $\mathrm{N}=6$. 
Role of NADPH Oxidase in PMN Priming by TNF- $\alpha$

Based on the marked reduction in the primed respiratory burst seen under anaerobic conditions, we reasoned that NADPH oxidase might be required for the oxygendependent component of priming. We studied cell surface protein expression in control cells versus PMN treated with DPI. We found that unstimulated (no Ag) and DPI-treated PMN had a similar degree of enhancement in $\mathrm{CD} 11 \mathrm{~b}$ and gp91 ${ }^{\text {phox }}$ cell surface expression following priming with TNF- $\alpha$ (fig. 9a, b). These data suggest that surface protein mobilization in response to TNF- $\alpha$-mediated priming is not NADPH oxidase dependent. We did see upregulation of cell surface protein expression in response to treatment by DPI alone, as we have previously described [7]. To further assess this phenotype, we studied the effect of TNF- $\alpha$ priming on PMN from two patients with chronic granulomatous disease who lack functional NADPH oxidase. Interestingly, human PMN lacking NADPH oxidase function also demonstrated increased CD11b surface expression compared to normal control PMN under both unstimulated and TNF- $\alpha$ priming conditions (fig. 9c). Together, these data suggest that NADPH oxidase-dependent, basal oxidant signaling may be required to maintain cellular quiescence. We performed similar studies to determine whether priminginduced surface mobilization of intracellular protein stores was regulated in an oxygen-sensitive manner. Control PMN were primed aerobically or anaerobically with TNF- $\alpha(10 \mathrm{ng} / \mathrm{ml})$ for $10-60 \mathrm{~min}$. At the specified time points, cells were placed on ice and removed from the anaerobic chamber for processing for flow cytometry. Surprisingly, PMN primed with TNF- $\alpha$ under anaerobic conditions had more rapid enhancement of surface CD11b levels than those cells primed under identical, but normoxic, conditions. At the 30 -min time point, anaerobically primed cells had a 1.9-fold enhancement in cell surface CD11b levels versus 1.4-fold in the aerobically primed cells compared with controls. By $60 \mathrm{~min}$, both aerobic and anaerobically primed PMN had nearly identical levels of surface protein mobilization (fig. 9d). Based on our concerns that these data might be altered by the $\mathrm{PMN}$ isolation process and inadvertant priming during isolation, we repeated these analyses on whole blood under aerobic and anaerobic conditions. Kinetic analysis of PMN studied in whole blood demonstrated TNF- $\alpha$-elicited changes in CD11b surface levels that were similar to our data from PMN isolated by standard techniques (fig. 9e). Taken together, these studies suggest that mobilization of intracellular stores of proteins occurs rapidly in response to TNF- $\alpha$, does not require NADPH oxidase function and occurs in an oxygen-independent manner. Moreover, this phenotypic response is not an artifact of cell isolation and may represent a mechanism for enhanced cell motility under appropriate conditions.

\section{Discussion}

In vivo, TNF- $\alpha$ stimulation of human PMN occurs under a broad range of clinical conditions; however, the highest circulating levels of TNF- $\alpha$ have been documented early in the course of bacterial sepsis and during septic shock. In this setting, the requirement for PMN as an essential cellular component of the innate immune response is unequivocal, but the potential for host tissue damage by release of activated neutrophil products is significant. Host modulation of PMN activation states is accomplished by a number of mechanisms, including PMN priming.

In the current study we explored in vitro neutrophil priming by the cytokine TNF- $\alpha$. Although PMN priming by TNF- $\alpha$ has been extensively studied, the literature is difficult to synthesize due to the broad range of protocols and concentrations of TNF- $\alpha$ used. The present work demonstrates two novel findings. First, TNF- $\alpha$-mediated priming of the respiratory burst in response to $\mathrm{MLF}$ is a partially oxygen-dependent process. However, TNF- $\alpha$ elicited upregulation of CD11b and activation of p38 MAPK occurs in an NADPH oxidase-independent manner. These data are in direct contrast to our findings with endotoxin-elicited priming. Second, the myelocytic PLB cell line can be differentiated to behave in a fashion similar to PMN and can be used as a genetically modifiable adjunct in priming studies. Moreover, we sought to investigate priming by TNF- $\alpha$ at a range of concentrations for each endpoint to determine which elements of the primed phenotype were elicited at pathophysiological levels of TNF- $\alpha$ (that is, levels routinely demonstrated in the circulation of septic patients). Interestingly, priming of PMN occurred in response to picogram per milliliter TNF- $\alpha$ concentrations, which are substantially lower than most investigators have studied and well within the range found in plasma during sepsis [9-11]. The signaling mechanisms elicited by these pathophysiological TNF- $\alpha$ concentrations are currently under investigation in our laboratory.

Several signaling proteins required for priming of PMN by TNF- $\alpha$ have already been identified. A role for p38 MAPKs and ERKs, but not JNKs, was first described in priming of the PMN respiratory burst by TNF- $\alpha$ and GM-CSF more than 10 years ago [18]. It is now evident 
that p38 MAPK is specifically involved in the phosphorylation of serine 345 on $\mathrm{p}^{\text {phox }}$, a cytosolic component of the NADPH oxidase [15]. Furthermore, this phosphorylation event is required for TNF- $\alpha$ priming of the respiratory burst [16]. p47 ${ }^{\text {phox }}$ undergoes a series of phosphorylation events that are required for assembly of the multicomponent NADPH oxidase, but these data were the first evidence for a direct link between phosphorylation of a specific residue and a downstream functional endpoint [32].

Although we were the first to demonstrate an NADPH oxidase-dependent component of priming in neutrophil responses to endotoxin in vitro [7], the concept of ROS signaling involvement in priming has been suggested previously [33]. A role for NADPH oxidase-derived ROS as a signaling intermediary involved in the priming process challenges two fundamental concepts in neutrophil biology. First, the long-standing model of PMN NADPH oxidase activation suggests that nonphagocytic stimuli generate only extracellular ROS [32]. However, our previously published data exploring endotoxin priming [7] and results of the current investigation support our contention that oxidant generation into an intracellular compartment occurs in response to priming stimuli. Furthermore, a number of investigators have presented evidence that intracellular NADPH oxidase assembly occurs in the absence of a phagocytic stimulus with proposed generation of ROS into granular or vesicular structures [34-36]. The specific nature of these compartments has yet to be defined. Second, by the classical definition of priming, activation of the NADPH oxidase does not occur in response to the priming stimulus alone. We demonstrate here, and have previously published [7], that ROS are in fact generated in response to priming concentrations of TNF- $\alpha$ or endotoxin, although this is low-level ROS synthesis as compared to the primed burst in response to fMLF. Together, these data require an alteration in our understanding of the phenotypes of the primed cell and mechanisms of priming.

Although cellular responses to the inflammatory stimulus TNF- $\alpha$ and the bacterial product endotoxin are often grouped together based on the fact that both stimuli elicit NF- $\kappa \mathrm{B}$ activation [37], the current investigation demonstrates that the mechanisms involved in TNF- $\alpha$ mediated priming are distinct from the PMN priming response to endotoxin. The TNF- $\alpha$ priming process had both oxygen-dependent and oxygen-independent components. Specifically, the current study demonstrates that protein mobilization to the cell surface did not require $\mathrm{NADPH}$ oxidase-derived ROS, but rather occurred in an oxygen-independent manner. Moreover, activation of p38 MAPK occurred independently of NADPH oxidase activity. Bouaouina et al. [33] had previously suggested that p38 MAPK activation in PMN by TNF- $\alpha$ was redox regulated. In addition, Src family tyrosine kinases are involved in TNF- $\alpha$ - mediated $\beta_{2}$-integrin activation, important for cell adhesion. Interpretation of these described investigations of TNF- $\alpha$-elicited cell signaling is complicated by the use of supraphysiologic concentrations of TNF- $\alpha$ for cell stimulation and limited analysis of the specific role of NADPH oxidase derived ROS. Further work is necessary to determine if cellular responses to picogram per milliliter concentrations of TNF- $\alpha$ are qualitatively similar to those seen in response to concentrations $>10 \mathrm{ng} / \mathrm{ml}$.

These considerations regarding correlations between cellular responses and the concentration of cytokine studied seem particularly relevant in view of the chemotaxis data presented here. We found that $10 \mathrm{ng} / \mathrm{ml} \mathrm{TNF}$ $\alpha$, a commonly employed concentration in priming studies, significantly inhibited PMN chemotaxis, while $1 \mathrm{pg} /$ $\mathrm{ml}$ enhanced directional movement in both PMN and PLB-D cells. These findings may be of particular clinical relevance as we begin to better understand the balance between pro- and anti-inflammatory host responses to infection. Monocyte-derived TNF- $\alpha$ levels may vary widely during the host response to severe sepsis - from very high during the hyperinflammation phase to very low during the immunoparalysis phase [38] - and it appears that this may respectively impede or enhance PMN chemotaxis to sites of infection. Mortality rates associated with uncontrolled pro- or anti-inflammatory states are extremely high and understanding PMN function in vivo during these clinical conditions remains an area of intense research.

Our characterization of priming responses in the differentiated PLB cell line is likely to facilitate many future studies, as these genetically modifiable cells will assist with manipulation of signaling proteins. A single previous investigation demonstrates priming in this cell type in response to GM-CSF [22], but our report is the first to study PLB 985 cell responses to inflammatory cytokines. There is a growing literature utilizing cell lines differentiated to neutrophil-like phenotypes for genetic manipulation, in combination with studies of primarily isolated PMN. In fact, mutagenesis was utilized in human promyelocytic leukemia HL-60 cells to define the critical serine residue of $\mathrm{p} 47^{\text {phox }}$ required for priming in response to TNF- $\alpha$ [16]. Although the limitations of these cell lines have been extensively documented by others, it is clear 
that when used in combination with PMN, PLB 985 cell studies will augment in-depth investigation of the signaling pathways involved in PMN function.

In conclusion, we have confirmed that several reported phenotypic endpoints of TNF- $\alpha$-mediated priming occur in response to picogram per milliliter concentrations of TNF- $\alpha$. We have demonstrated that differentiated PLB-985 cells undergo priming in response to these physiologically relevant concentrations of TNF- $\alpha$, with increased NADPH oxidase activity, enhanced surface mobilization of the gp91 $91^{\text {phox }}$ subunit of the flavocytochrome $b_{558}$ and the $\beta_{2}$-integrin CD11b, and augmented chemotaxis, all important endpoints of PMN priming.
This investigation has also demonstrated that while TNF$\alpha$-mediated priming of the respiratory burst is partially oxygen dependent, other priming endpoints are not similarly redox regulated. Understanding the oxidant-sensitive and oxygen-independent components of the TNF- $\alpha$ signaling pathways elicited in PMN is a current priority in our laboratory.

\section{Acknowledgments}

This work was supported by the following NIH-grants: AI079445, HD047349 and HD027748 to A.P.D.V.; AI073872 to J.G.M.

\section{References}

-1 Martin GS, Mannino DM, Eaton S, Moss M: The epidemiology of sepsis in the United States from 1979 through 2000. N Engl J Med 2003;348:1546-1554.

$>2$ Poulton B: Advances in the management of sepsis: the randomised controlled trials behind the Surviving Sepsis Campaign recommendations. Int J Antimicrob Agents 2006; 27:97-101.

-3 Bass DA, Olbrantz P, Szejda P, Seeds MC, McCall CE: Subpopulations of neutrophils with increased oxidative product formation in blood of patients with infection. J Immunol 1986;136:860-866.

4 Drost EM, Kassabian G, Meiselman HJ, Gelmont D, Fisher TC: Increased rigidity and priming of polymorphonuclear leukocytes in sepsis. Am J Respir Crit Care Med 1999; 159:1696-1702.

$>5$ Chollet-Martin S, Montravers P, Gibert C, Elbim C, Desmonts JM, Fagon JY, GougerotPocidalo MA: Subpopulation of hyperresponsive polymorphonuclear neutrophils in patients with adult respiratory distress syndrome. Role of cytokine production. Am Rev Respir Dis 1992;146:990-996.

6 Sheppard FR, Kelher MR, Moore EE, McLaughlin NJ, Banerjee A, Silliman CC: Structural organization of the neutrophil NADPH oxidase: phosphorylation and translocation during priming and activation. J Leukoc Biol 2005;78:1025-1042.

7 Moreland JG, Davis AP, Matsuda JJ, Hook JS, Bailey G, Nauseef WM, Lamb FS: Endotoxin priming of neutrophils requires NADPH oxidase-generated oxidants and is regulated by the anion transporter clc-3. J Biol Chem 2007;282:33958-33967.

$>8$ Condliffe AM, Kitchen E, Chilvers ER: Neutrophil priming: pathophysiological consequences and underlying mechanisms. Clin Sci (Lond) 1998;94:461-471.
9 Casey LC, Balk RA, Bone RC: Plasma cytokine and endotoxin levels correlate with survival in patients with the sepsis syndrome. Ann Intern Med 1993;119:771-778.

10 Calandra T, Baumgartner JD, Grau GE, Wu MM, Lambert PH, Schellekens J, Verhoef J, Glauser MP: Prognostic values of tumor necrosis factor/cachectin, interleukin-1, interferon- $\alpha$, and interferon- $\gamma$ in the serum of patients with septic shock. Swiss-Dutch j5 Immunoglobulin Study Group. J Infect Dis 1990;161:982-987.

-11 Heper Y, Akalin EH, Mistik R, Akgoz S, Tore O, Goral G, Oral B, Budak F, Helvaci S: Evaluation of serum c-reactive protein, procalcitonin, tumor necrosis factor $\alpha$, and interleukin-10 levels as diagnostic and prognostic parameters in patients with community-acquired sepsis, severe sepsis, and septic shock. Eur J Clin Microbiol Infect Dis 2006;25:481491.

12 Elbim C, Chollet-Martin S, Bailly S, Hakim J, Gougerot-Pocidalo MA: Priming of polymorphonuclear neutrophils by tumor necrosis factor- $\alpha$ in whole blood: identification of two polymorphonuclear neutrophil subpopulations in response to formyl-peptides. Blood 1993;82:633-640.

13 Lauterbach M, O’Donnell P, Asano K, Mayadas TN: Role of TNF priming and adhesion molecules in neutrophil recruitment to intravascular immune complexes. J Leukoc Biol 2008;83:1423-1430.

14 Montecucco F, Steffens S, Burger F, Da Costa A, Bianchi G, Bertolotto M, Mach F, Dallegri F, Ottonello L: Tumor necrosis factor- $\alpha$ $(\mathrm{TNF}-\alpha)$ induces integrin CD11B/CD18 (Mac-1) up-regulation and migration to the CC chemokine CCL3 (MIP-1 $\alpha$ ) on human neutrophils through defined signalling pathways. Cell Signal 2008;20:557-568.
15 Dewas C, Dang PM, Gougerot-Pocidalo MA, El-Benna J: TNF- $\alpha$ induces phosphorylation of p47(phox) in human neutrophils: partial phosphorylation of $\mathrm{p} 47$ phox is a common event of priming of human neutrophils by TNF- $\alpha$ and granulocyte-macrophage colony-stimulating factor. J Immunol 2003;171: 4392-4398.

16 Dang PM, Stensballe A, Boussetta T, Raad H, Dewas C, Kroviarski Y, Hayem G, Jensen ON, Gougerot-Pocidalo MA, El-Benna J: A specific p47phox-serine phosphorylated by convergent MAPKs mediates neutrophil NADPH oxidase priming at inflammatory sites. J Clin Invest 2006;116:2033-2043.

17 Condliffe AM, Davidson K, Anderson KE, Ellson CD, Crabbe T, Okkenhaug K, Vanhaesebroeck B, Turner M, Webb L, Wymann MP, Hirsch E, Ruckle T, Camps M, Rommel C, Jackson SP, Chilvers ER, Stephens LR, Hawkins PT: Sequential activation of class IB and class IA PI3K is important for the primed respiratory burst of human but not murine neutrophils. Blood 2005;106:1432-1440.

18 McLeish KR, Knall C, Ward RA, Gerwins P, Coxon PY, Klein JB, Johnson GL: Activation of mitogen-activated protein kinase cascades during priming of human neutrophils by TNF- $\alpha$ and GM-CSF. J Leukoc Biol 1998; 64:537-545.

19 Blouin E, Halbwachs-Mecarelli L, Rieu P: Redox regulation of beta2-integrin cd11b/ cd18 activation. Eur J Immunol 1999;29: 3419-3431.

20 Watson RW: Redox regulation of neutrophil apoptosis. Antioxid Redox Signal 2002;4:97104.

21 Boyum A: Isolation of mononuclear cells and granulocytes from human blood. Isolation of monuclear cells by one centrifugation, and of granulocytes by combining centrifugation and sedimentation at $1 \mathrm{~g}$. Scand J Clin Lab Invest Suppl 1968;97:77-89. 
-22 Pedruzzi E, Fay M, Elbim C, Gaudry M, Gougerot-Pocidalo MA: Differentiation of PLB-985 myeloid cells into mature neutrophils, shown by degranulation of terminally differentiated compartments in response to $\mathrm{N}$-formyl peptide and priming of superoxide anion production by granulocyte-macrophage colony-stimulating factor. $\mathrm{Br} \mathrm{J}$ Haematol 2002;117:719-726.

23 Gabig TG, Bearman SI, Babior BM: Effects of oxygen tension and $\mathrm{pH}$ on the respiratory burst of human neutrophils. Blood 1979;53: 1133-1139.

24 Liu L, Harbecke O, Elwing H, Follin P, Karlsson A, Dahlgren C: Desensitization of formyl peptide receptors is abolished in calcium ionophore-primed neutrophils: an association of the ligand-receptor complex to the cytoskeleton is not required for a rapid termination of the NADPH-oxidase response. J Immunol 1998;160:2463-2468.

25 Volk AP, Heise CK, Hougen JL, Artman CM, Volk KA, Wessels D, Soll DR, Nauseef WM, Lamb FS, Moreland JG: CLC-3 and IClswell are required for normal neutrophil chemotaxis and shape change. J Biol Chem 2008; 283:34315-34326.
6 Kanegasaki S, Nomura Y, Nitta N, Akiyama S, Tamatani T, Goshoh Y, Yoshida T, Sato T, Kikuchi Y: A novel optical assay system for the quantitative measurement of chemotaxis. J Immunol Methods 2003;282:1-11.

27 Tucker KA, Lilly MB, Heck L Jr, Rado TA: Characterization of a new human diploid myeloid leukemia cell line (PLB-985) with granulocytic and monocytic differentiating capacity. Blood 1987;70:372-378.

28 Kharazmi A, Nielsen H, Bendtzen K: Modulation of human neutrophil and monocyte chemotaxis and superoxide responses by recombinant TNF- $\alpha$ and GM-CSF. Immunobiology 1988;177:363-370.

29 Atkinson YH, Marasco WA, Lopez AF, Vadas MA: Recombinant human tumor necrosis factor- $\alpha$. Regulation of N-formylmethionylleucylphenylalanine receptor affinity and function on human neutrophils. J Clin Invest 1988;81:759-765.

0 Bajaj MS, Kew RR, Webster RO, Hyers TM: Priming of human neutrophil functions by tumor necrosis factor: enhancement of superoxide anion generation, degranulation, and chemotaxis to chemoattractants C5a and F-Met-Leu-Phe. Inflammation 1992;16: 241-250.

- 31 Lokuta MA, Huttenlocher A: TNF- $\alpha$ promotes a stop signal that inhibits neutrophil polarization and migration via a 38 MAPK pathway. J Leukoc Biol 2005;78:210-219.
32 Nauseef WM: Assembly of the phagocyte NADPH oxidase. Histochem Cell Biol 2004; 122:277-291

33 Bouaouina M, Blouin E, Halbwachs-Mecarelli L, Lesavre P, Rieu P: TNF-induced $\beta 2$ integrin activation involves SRC kinases and a redox-regulated activation of p38 mapk. J Immunol 2004;173:1313-1320.

34 Kobayashi T, Robinson JM, Seguchi H: Identification of intracellular sites of superoxide production in stimulated neutrophils. J Cell Sci 1998;111:81-91.

35 Karlsson A, Dahlgren C: Assembly and activation of the neutrophil NADPH oxidase in granule membranes. Antioxid Redox Signal 2002;4:49-60.

- 36 Ambruso DR, Cusack N, Thurman G: NADPH oxidase activity of neutrophil specific granules: requirements for cytosolic components and evidence of assembly during cell activation. Mol Genet Metab 2004; 81:313-321.

37 Muller JM, Ziegler-Heitbrock HW, Baeuerle PA: Nuclear factor $\kappa$ B, a mediator of lipopolysaccharide effects. Immunobiology 1993; 187:233-256.

38 Frazier WJ, Hall MW: Immunoparalysis and adverse outcomes from critical illness. Pediatr Clin North Am 2008;55:647-668, xi. 